Article

\title{
Production Performance, Nutrient Digestibility, and Milk Composition of Dairy Ewes Supplemented with Crushed Sunflower Seeds and Sunflower Seed Silage in Corn Silage-Based Diets
}

\author{
Eduardo Cardoso-Gutiérrez ${ }^{1}$, Alondra Cristel Narváez-López ${ }^{2}$, Lizbeth E. Robles-Jiménez ${ }^{1}$, \\ Andrés Morales Osorio ${ }^{3}$, María de Guadalupe Gutierrez-Martinez ${ }^{3}$, Heidi Leskinen ${ }^{4}(\mathbb{D}$, \\ Marcello Mele ${ }^{5}$, Einar Vargas-Bello-Pérez ${ }^{6, *(\mathbb{D})}$ and Manuel González-Ronquillo ${ }^{1, * \text { (D }}$ \\ 1 Facultad de Medicina Veterinaria y Zootecnia, Instituto Literario 100, Universidad Autónoma del Estado \\ de México, Toluca CP 50000, Mexico; cardosoge89@gmail.com (E.C.-G.); lizroblez@hotmail.com (L.E.R.-J.) \\ 2 Division Académica de Ciencias Agropecuarias, Universidad Juárez Autónoma de Tabasco, Carr. \\ Villahermosa-Teapa, km 25, Villahermosa, Tabasco CP 86280, Mexico; londycristel1996@gmail.com \\ 3 Facultad de Ciencias Agricolas, Instituto Literario 100, Universidad Autónoma del Estado de México, \\ Toluca CP 50000, Mexico; amosorio47@yahoo.com.mx (A.M.O.); mggutierrezm@uaemex.mx (M.d.G.G.-M.) \\ 4 Milk Production, Production Systems, Natural Resources Institute Finland (Luke), FI 31600 Jokioinen, \\ Finland; heidi.leskinen@luke.fi \\ 5 Dipartimento di Scienze Agrarie, Alimentari e Agro-Ambientali, Università di Pisa, Via del Borghetto 80, \\ 56124 Pisa, Italy; marcello.mele@unipi.it \\ 6 Department of Veterinary and Animal Sciences, Faculty of Health and Medical Sciences, University of \\ Copenhagen, Grønnegårdsvej 3, 1870 Frederiksberg C, Denmark \\ * Correspondence: evargasb@sund.ku.dk (E.V.-B.-P.); mrg@uaemex.mx (M.G.-R.)
}

Received: 10 November 2020; Accepted: 4 December 2020; Published: 9 December 2020

check for updates

Simple Summary: In countries such as Mexico and the Unites States, sunflowers can be planted earlier than corn, and can tolerate moderate frosts. Concerning sunflower silage, its feeding value could be up to $80 \%$ similar to that of corn silage. The use of sunflower silage for ruminant feeding represents an alternative to the use of corn silage, especially when environmental conditions are adverse for corn crops. Sunflower seeds can also be a protein alternative to soybean by-products. This study determined production performance, nutrient digestibility, and milk composition of dairy ewes fed with crushed sunflower seeds (SF) and sunflower seed silage (SFS) in corn silage-based diets. Compared to control, SF and SFS increased intake and digestibility of fiber components, such as neutral detergent fiber (NDF) and acid detergent fiber (ADF). Nitrogen balance, milk yield, milk fat yield, and milk protein yield were similar between treatments. Results demonstrated that crushed sunflower seeds and ensiled seeds do not change significantly productive parameters of dairy sheep. In corn-silage based diets, both crushed and ensiled sunflower seeds can be used in dairy sheep diets as alternatives to typical protein feedstuffs, such as soybean meal.

\begin{abstract}
This study determined production performance, nutrient digestibility, and milk composition of dairy ewes supplemented with crushed sunflower seeds (Helianthus annuus) and sunflower seed silage in corn silage-based diets. Six ewes were grouped in a double $3 \times 3$ Latin square design with three periods of 21 days. All treatments were based on ad libitum corn silage. Control diet was based on alfalfa hay (333 g/kg DM), sorghum grain (253 g/kg DM), triticale grain ( $200 \mathrm{~g} / \mathrm{kg} \mathrm{DM})$, soybean meal (167 g/kg DM), and vitamin and mineral premix (47 g/kg DM). Sunflower seeds (SF) and sunflower seed silage (SFS) treatments consisted of alfalfa hay (333 g/ $\mathrm{kg} \mathrm{DM})$, sorghum grain (267 g/kg DM), triticale grain (100 g/kg DM), soybean meal (167 g $/ \mathrm{kg} \mathrm{DM),} \mathrm{SF} \mathrm{or} \mathrm{SFS} \mathrm{(87} \mathrm{g/kg} \mathrm{DM)}$ and vitamin and mineral premix (47 g/kg DM). Compared to control, SF and SFS increased intake and digestibility of fiber components, such as neutral detergent fiber (NDF) and acid detergent fiber
\end{abstract}


(ADF). Body weight, nitrogen balance, milk yield, milk fat yield, milk protein yield, lactose yield and milk urea $\mathrm{N}$ were similar between treatments. Overall, results demonstrated that crushed sunflower seeds and ensiled seeds do not change significantly productive parameters of dairy sheep.

Keywords: sheep; oilseeds; rumen; digestibility; sunflower

\section{Introduction}

After soybean, sunflower is one of the world's most important oilseed crops used for oil production, and it is high in oleic acid [1]. Sunflower seeds are mostly produced for oil extraction, but can also be used as a protein source for monogastric and ruminant animals, as they provide high contents of fat (380-540 g/kg) and protein (140-200 g/kg) [2].

In countries such as Mexico and the Unites States, sunflowers can be sowed earlier than corn, and can tolerate moderate frosts. Concerning sunflower silage, its feeding value could be up to $80 \%$ similar to that of corn silage. The main difference is that whole-plant sunflower silage has more crude protein and fat than corn silage [3]. Moreover, sunflower is usually cultivated under rainfed conditions, whereas corn cultivation is usually associated with high water consumption for irrigation. Therefore, the use of sunflower silage for ruminant feeding represent an alternative to the use of corn silage, especially when environmental conditions are adverse for corn crops. Moreover, oilseed oil by-products, such as sunflower meal and rapeseed meal, could be alternative protein feedstuffs instead of using soybean meal in sheep diets [4,5].

Adding oilseeds to lactating ewe diets can improve milk fatty acid profiles. Zhang et al. [6] described how dietary supplementation with seeds of canola, sunflower, or flaxseed can be used to modify milk fatty acid structure towards a healthier profile for human consumption, without effects on dry matter intake or nutrient utilization. Oilseed by-products have been used in ewe's diets. For example, supplementation of sunflower oilcake at indoor or outdoor feeding systems has been shown to improve the content of total unsaturated milk fatty acids without deleterious outcomes on milk production and milk composition [7]. In grazing ewes, sunflower seeds have shown to improve the content of polyunsaturated fatty acids without affecting milk yield [8].

Today, no studies are available in the literature that concurrently relate the effects of feeding different sunflower products to dairy ewes. Therefore, the aim of this study was to quantify milk production, nutrient digestibility, and milk composition of dairy ewes supplemented with crushed sunflower seeds and sunflower seed silage in corn silage-based diets. The hypothesis of this study was that the type of sunflower seed supplementation (as a crushed seed or as a seed silage) affects production performance, nutrient digestibility, and milk composition. Our data will be important for sheep farmers looking for alternative energy and protein feedstuffs.

\section{Materials and Methods}

\subsection{Animal Conditions and Experimental Diets}

Animal procedures were approved by the Animal Experimental Guidelines of the Universidad Autonoma del Estado de México (project code UAEMex 4974/2020).

The study was performed at the Universidad Autónoma del Estado de México. Six primiparous East-Friesian ewes with $70 \pm 5$ days in milk were fed with three diets according to double $3 \times 3$ Latin square design, with $21 \mathrm{~d}$ experimental periods. Each experimental period consisted of $15 \mathrm{~d}$ for diet adaptation and $6 \mathrm{~d}$ for sample collection. During the study, animals were assigned into individual metabolic cages $(1.2 \times 0.8 \mathrm{~m})$, fed twice daily (08:00 and 15:00 hours) with continuous water supply, and milked manually, daily, at 16:00 hours. 
All treatments contained corn silage ad libitum. Control diet contained alfalfa hay (333 g/kg DM), sorghum grain (253 g/kg DM), triticale grain (200 g/kg DM), soybean meal (167 g $/ \mathrm{kg} \mathrm{DM})$, and vitamin and mineral premix (47 g/kg DM; Multitec of Malta ${ }^{\circledR}$, Guanajuato, Mexico).

Crushed sunflower seed (SF) and sunflower seed silage (SFS) diets were composed by alfalfa hay (333 g/kg DM), sorghum grain (267 g/kg DM), triticale grain (100 g/kg DM), soybean meal (167 g / kg $\mathrm{DM})$, SF or SFS (87 g/kg DM) and vitamin and mineral premix (47 g/kg DM; Multitec of Malta ${ }^{\circledR}$, Guanajuato, Mexico). Chemical composition of ingredients used in the experimental diets is shown in Table 1.

Sunflower seed silage was prepared as follows: $50 \mathrm{~kg}$ of sunflower seeds were crushed into $2 \mathrm{~mm}$ particles. The next step was the addition of water $1: 1$ ratio and $0.001 \%$ fresh Pulque as an inoculant to accelerate the fermentation process [9]. Pulque is a Mexican fermented beverage readily available around the region where the study was carried out, which is rich in lactic acid bacteria $\left(1.5 \times 10^{8} \mathrm{CFU} / \mathrm{mL}\right)$, aerobic mesophilic bacteria $\left(1.2 \times 10^{7} \mathrm{CFU} / \mathrm{mL}\right)$, and yeast $\left(1.9 \times 10^{7} \mathrm{CFU} / \mathrm{mL}\right)[10]$. After Pulque inoculation, the crushed seeds with water and Pulque were homogenized (pre-silage). Then, placed in layers, compacted, sealed, and ensiled in 25-kg plastic bags $(n=4)$. The plastic bags were placed hard-plastic containers (975 mm height, $594 \mathrm{~mm} \varnothing$, and $208 \mathrm{~L}$ of capacity) with a hard cover, and sealed to avoid rodents and birds presence. Silages were fermented for 24 days, until their use for feeding animals. This silage-making method is similar to conventional methods used for corn silage-making; however, in this case we used a local fermented beverage as a natural inoculant.

Table 1. Chemical composition $(\mathrm{g} / \mathrm{kg} \mathrm{DM})$ of ingredients included in the dietary treatments formulation.

\begin{tabular}{|c|c|c|c|c|c|c|c|}
\hline Ingredient & Corn Silage & Alfalfa Hay & Sorghum Gain & $\begin{array}{l}\text { Triticale } \\
\text { Grain }\end{array}$ & $\begin{array}{c}\text { Soybean } \\
\text { Meal }\end{array}$ & SF & SFS \\
\hline Dry matter & 270 & 900 & 932 & 900 & 923 & 927 & 553 \\
\hline Organic matter & 939 & 900 & 919 & 934 & 905 & 961 & 955 \\
\hline Crude protein & 84 & 180 & 80 & 123 & 443 & 205 & 257 \\
\hline Ether extract & 16.8 & 30 & 26.7 & 25 & 11.9 & 281 & 378 \\
\hline Neutral detergent fiber & 545 & 550 & 46 & 231 & 70 & 408 & 331 \\
\hline Acid detergent fiber & 322 & 330 & 23 & 64 & 37 & 333 & 238 \\
\hline $\mathrm{ME}, \mathrm{MJ} / \mathrm{kg} \mathrm{DM}^{1}$ & 11 & 10 & 13 & 13.2 & 13.6 & 17.5 & 17.5 \\
\hline
\end{tabular}

${ }^{1}$ Calculated from NRC [11]. SF = crushed sunflower seed; SFS = sunflower seed silage; ME = metabolizable energy.

Dietary treatments were elaborated to satisfy energy and protein requirements of dairy ewes in mid-lactation [11]. Dietary treatments were balanced to theoretically contain $115 \mathrm{~g} / \mathrm{kg}$ of crude protein and 10.04 MJ of metabolizable energy (ME)/kg DM [11].

The concentrate was supplied twice daily at 08:00 and 16:00 hours. Depending on the treatment, amounts of concentrate per animal per day were: $752 \mathrm{~g}$ for control, $798 \mathrm{~g}$ for SF, and $869 \mathrm{~g}$ for SFS. The concentrate was made in batches of $100 \mathrm{~kg}$ by manually mixing the ingredients for each diet. Concentrate and forages were offered separately as each individual stall had a feed bunk divided in two spaces. Chemical composition of the dietary treatments is shown in Table 2.

\subsection{Sampling and Measurements}

In each experimental period, samples of corn silage, alfalfa hay, concentrate, and treatments were collected every day and stored at $-20^{\circ} \mathrm{C}$. Dietary treatments, orts, and fecal samples were dried in a forced-air oven at $60{ }^{\circ} \mathrm{C}$ for $48 \mathrm{~h}$. Once dried, they were ground with a Wiley mill (2.0 mm screen; Arthur H. Thomas, Philadelphia, PA, USA), and analyzed in duplicates for DM (930.15), organic matter (OM; 942.05), ether extract (method 920.39) and nitrogen (N; 990.02) using the Association of Official Analytical Chemists (AOAC) [12] standard methods. Neutral detergent fiber (NDF) and acid detergent fiber (ADF) were determined following Van Soest et al. [13] methods. Nutrient digestibility (g/kg) was determined as [(nutrient intake, g/d - nutrient excreted, $\mathrm{g} / \mathrm{d}) /($ nutrient intake, $\mathrm{g} / \mathrm{d})] \times 1000$.

Feces were collected every $24 \mathrm{~h}$ and sampled at $08: 00 \mathrm{~h}$ on the last 6 days of each period. Feces were collected from each individual stall that was equipped with a metallic container with a mesh frame. 
Feces were fully collected and used for calculations. A subsample of $10 \%$ was taken and stored at -20 ${ }^{\circ} \mathrm{C}$ until analysis.

Urine was collected every $24 \mathrm{~h}$ and sampled every day at 08:00 $\mathrm{h}$ during the last 6 days of each period. Urine samples were obtained using a metal container located under each individual stall that had a mesh filter screen to allow separation of urine from feces. Daily total volumes of urine were measured and then $10 \%$ of total samples was kept and frozen at $-20{ }^{\circ} \mathrm{C}$ for further analysis. Feces and urine samples were used to quantify nitrogen excretion. Total nitrogen in feces and urine was analyzed using micro-Kjeldahl analysis.

Individual body weight $(\mathrm{BW}, \mathrm{kg})$ and body weight change $(\mathrm{BWC}, \mathrm{g} / \mathrm{d})$ were registered the beginning and at the end of each experimental period. Dry matter intake (DMI, g/d) and individual milk yields $(\mathrm{kg} / \mathrm{d})$ were recorded every day but only data from the last 6 days of each period were used for statistical analysis.

Individual milk samples $(100 \mathrm{~mL})$ were collected on the last 6 days of each experimental period at 16:00 h using a volumetric milk meter and preserved with potassium dichromate (Merck, Fontenay-sous-Bois, France). Milk samples were analyzed in duplicates by infrared using a MilkoScan 133B (Foss Electric, Hillerød, Denmark) in order to determine total solids (TS) and non-fat solids (NFS). Milk protein was determined according to McKenzie and Murphy [14] and fat was determined by Levowitz method [15]. Milk urea nitrogen (MUN) was analyzed by the micro-Kjeldahl method, and the protein content was determined using a factor of 6.38 based on method 991.20 [12].

Fat-corrected milk (FCM 6.5\%, kg/d) and fat-protein corrected milk (FPCM 6.5, 5.8\%, kg/d were calculated according to Pulina et al. [16]. Feed efficiency (FE) was calculated as: FE = milk yield $(\mathrm{kg} / \mathrm{d}) / \mathrm{dry}$ matter intake $(\mathrm{kg} / \mathrm{d})$. Adjusted FE was calculated as [6.5\% FCM $(\mathrm{kg} / \mathrm{d}) / \mathrm{DMI}(\mathrm{kg} / \mathrm{d})]$.

Table 2. Inclusion of ingredients (g/kg DM) and chemical composition ( $/ \mathrm{kg} \mathrm{DM}$ ) of control, sunflower seeds (SF) and sunflower seeds silage (SFS) treatments.

\begin{tabular}{|c|c|c|c|}
\hline \multirow{2}{*}{ Ingredients } & \multicolumn{3}{|c|}{ Treatments } \\
\hline & Control & SF & SFS \\
\hline Corn silage & Ad libitum & Ad libitum & Ad libitum \\
\hline Alfalfa hay & 333 & 333 & 333 \\
\hline Sorghum grain & 253 & 267 & 267 \\
\hline Triticale grain & 200 & 100 & 100 \\
\hline Soybean meal & 167 & 167 & 167 \\
\hline Crushed sunflower seeds & 0 & 87 & 0 \\
\hline Sunflower seed silage & 0 & 0 & 87 \\
\hline Vitamin and mineral premix ${ }^{1}$ & 47 & 47 & 47 \\
\hline \multicolumn{4}{|c|}{ Chemical composition } \\
\hline Dry matter & 905 & 928 & 903 \\
\hline Organic matter & 870 & 873 & 872 \\
\hline Crude protein & 179 & 185 & 190 \\
\hline Ether extract & 24 & 46 & 54 \\
\hline Neutral detergent fiber & 253 & 266 & 259 \\
\hline Acid detergent fiber & 135 & 158 & 149 \\
\hline Metabolizable energy, MJ (kg DM $\left.{ }^{2}\right)$ & 11.5 & 11.9 & 11.9 \\
\hline
\end{tabular}

\footnotetext{
${ }^{1}$ Containing in $1.0 \mathrm{~kg}$ DM the following: $25 \mathrm{mg}$ of antioxidant, $4.5 \mathrm{~g}$ of calcium carbonate, $6 \mathrm{~g}$ of salt, $30 \mathrm{~g}$ of ionophore, $50 \mathrm{~g}$ of zinc oxide, $6 \mathrm{~g}$ of sodium bicarbonate, $6 \mathrm{~g}$ of copper sulfate, $20 \mathrm{~g}$ of ferrous sulfate, $125 \mathrm{~g}$ of sodium sulfate, 18,000 IU of vitamin E, 3,000,000 IU of vitamin A, 3,750,000 IU of vitamin D, $140 \mathrm{~g}$ of potassium chloride, $0.500 \mathrm{~g}$ of EDD. I ethylene-dynamine, $0.090 \mathrm{~g}$ of cobalt carbonate, $500 \mathrm{mg}$ of magnesium oxide, $36 \mathrm{~g}$ of manganese oxide and $0.090 \mathrm{~g}$ of selenium. ${ }^{2}$ Calculated from NRC [11].
}

\subsection{In Vitro Gas Production}

Each dietary treatment and pure ruminal fluid were used to determine in vitro gas production [17]. A total of $0.800 \mathrm{~g}$ DM of each dietary treatment was put into glass flasks bottles by triplicate in two tandems and repeated for four incubation runs (total of 24 bottles of each diet and treatment), with 
$90 \mathrm{~mL}$ of buffer solution and $10 \mathrm{~mL}$ of sheep rumen fluid. The buffer solution composition has been reported previously [18]. Three sheep ( $42 \pm 2 \mathrm{~kg}$ of live weight) from the same herd fed on the control diet were used as donors of ruminal fluid, which was extracted, filtered in triple cheesecloth gauze, and homogenized with $\mathrm{CO}_{2}$. The bottles were incubated in a water bath at $39^{\circ} \mathrm{C}$. The volume of gas ( $\mathrm{ml}$ of gas/g DM) was recorded at 3, 6, 9, 12, 24, 36, 48, 60, 72, 84, and $96 \mathrm{~h}$ of incubation. The gas accumulated from each sample was adjusted to the model proposed by France et al. [19]. After $96 \mathrm{~h}$ of incubation period, $\mathrm{pH}$ and the dry matter disappearance (DMD) were determined. A completely randomized design was performed, and Tukey's test was used when differences between treatments were observed.

\subsection{Statistical Analysis}

Data from the last 6 days of each experimental periods were considered for statistical analysis. Data were subjected to ANOVA using the general linear model procedure of the SAS software package (2002), with a model that included the effects of ewe, period, and treatment in a Latin square design, where experimental period and treatment were considered fixed effects, and individual ewe the random effect. Least squares means with their standard errors are reported and significant treatment effects were declared at $p<0.05$.

\section{Results and Discussion}

\subsection{Nutrient Intake and Digestibility}

The live weight remained similar between treatments $(52.3 \pm 4.90 \mathrm{~kg})$ (Table 3). This was expected as diets had similar energy content and the dry matter intake did not change across treatments. Khotija et al. [20] suggested that the addition of sunflower seed is an efficient way to supply energy and that it helped to maintain the body conditions of postpartum lactating ewes, as observed in this study. Conversely, Ivan et al. [21] found a significant decrease from $240 \mathrm{~g}$ to $191 \mathrm{~g}$ in daily weight gains in growing lambs with the addition of crushed sunflower seed at $14 \%$ per $\mathrm{kg}$ DM in a high forage diet $(50 \% \mathrm{DM})$, and that was attributed to a decrease in DMI in response of the low digestibility of the forage. In the same study, but with a low dietary forage and protein (crushed sunflower seed), the average daily gain was higher due to the lower fiber content, even with a decrease DMI against control.

Both SF and SFS had no effect on DM $(1124 \pm 85.7 \mathrm{~g} / \mathrm{d})$ and OM $(1781 \pm 182 \mathrm{~g} / \mathrm{d})$ intakes (Table 3), which partly agrees with what was previously reported both in lactating sheep $[20,22,23]$ and goats $[24$, 25], when animals were fed with either sunflower seeds or sunflower oil. Gomez-Cortés et al. [23] obtained a rise in DM intake when sheep were supplemented with $2 \%$ DM sunflower oil in a diet, with a diet based on $50 \%$ forage and $50 \%$ concentrate; however, contrary to the present results, Ivan et al. [21], reported a decrease in DMI with low- and high-forage diets with two protein levels of crushed sunflower seed supplementation.

Compared to control, SF and SFS improved intake and digestibility of NDF and ADF (Table 3), while the SFS treatment obtained the highest digestibility of NDF and ADF. This was probably related to the toxic effect of polyunsaturated fatty acids (which are high in sunflower seeds) on the predatory ciliated protozoa of beneficial ruminal fauna (defaunation) that led to increase the populations of cellulolytic bacteria, improving digestibility of NDF and ADF. This effect was described previously in growing lambs fed on sunflower seeds [21].

\subsection{Nitrogen Balance}

Nitrogen balance was higher in ewes fed SF and SFS diets, while SFS increase milk $\mathrm{N}$ retention (Table 4). The amounts of $\mathrm{N}$ in feces $(6.77 \pm 0.93 \mathrm{~g} / \mathrm{d})$ were of higher magnitude than that observed in urine $(3.65 \pm 0.59 \mathrm{~g} / \mathrm{d})$, which suggests that there was a larger use of ruminal ammonia, causing a transfer of $\mathrm{N}$ from urine to feces [26]. 
Table 3. Intake $\left(\mathrm{g} / \mathrm{d}, \mathrm{g} / \mathrm{kg} \mathrm{LW} \mathrm{LW}^{0.75}\right)$ and digestibility coefficients $(\mathrm{kg} / \mathrm{kg})$ in dairy sheep fed control, sunflower seeds (SF), and sunflower seeds silage (SFS) treatments.

\begin{tabular}{|c|c|c|c|c|c|}
\hline & \multicolumn{3}{|c|}{ Treatment } & \multirow{2}{*}{ SEM } & \multirow{2}{*}{$p$-Value } \\
\hline & Control & SF & SFS & & \\
\hline Average body weight, BW, kg & 52.5 & 51.9 & 52.5 & 4.90 & 0.853 \\
\hline Average metabolic BW, g/kg LW 0.75 & 19.4 & 19.2 & 19.4 & 1.36 & 0.995 \\
\hline \multicolumn{6}{|c|}{ Intake, $\mathrm{g} / \mathrm{d}$} \\
\hline Dry matter & 1127 & 1100 & 1144 & 85.7 & 0.981 \\
\hline Forage:concentrate ratio & $1.37(57: 43)$ & $1.47(59: 41)$ & $1.21(55: 45)$ & 0.13 & 0.400 \\
\hline Organic matter & 1683 & 1860 & 1799 & 182 & 0.975 \\
\hline Crude protein & 251 & 297 & 318 & 25.5 & 0.199 \\
\hline Fat & $66^{\mathrm{b}}$ & $90 \mathrm{ab}$ & $124^{\mathrm{a}}$ & 12.6 & 0.017 \\
\hline Neutral detergent fiber & $530^{b}$ & $833^{\mathrm{a}}$ & $788^{a b}$ & 78.6 & 0.033 \\
\hline Acid detergent fiber & $259^{b}$ & $475^{\mathrm{a}}$ & $449^{a}$ & 43.8 & 0.006 \\
\hline \multicolumn{6}{|c|}{ Intake, $\mathrm{g} / \mathrm{kg} \mathrm{LW} \mathrm{W}^{0.75}$} \\
\hline Dry matter & 92.0 & 102 & 98.1 & 5.32 & 0.419 \\
\hline Forage intake & 53.3 & 60.9 & 53.7 & 5.21 & 0.524 \\
\hline Concentrate intake & $38.7^{\mathrm{b}}$ & $41.3^{\mathrm{ab}}$ & $44.3^{\mathrm{a}}$ & 0.84 & 0.001 \\
\hline Sunflower intake & $0.00^{\mathrm{c}}$ & $5.00^{\mathrm{b}}$ & $7.82^{\mathrm{a}}$ & 0.69 & 0.001 \\
\hline Organic matter & 85.8 & 96.0 & 92.2 & 4.95 & 0.362 \\
\hline Crude protein & $12.9^{b}$ & $15.3^{\mathrm{a}}$ & $16.2^{\mathrm{a}}$ & 0.39 & 0.001 \\
\hline Fat & $3.41^{b}$ & $4.65^{b}$ & $6.24^{\mathrm{a}}$ & 0.34 & 0.001 \\
\hline Neutral detergent fiber & $26.8^{b}$ & $43.0^{\mathrm{a}}$ & $40.4^{\mathrm{a}}$ & 2.32 & 0.001 \\
\hline Acid detergent fiber & $13.1^{\mathrm{b}}$ & $24.5^{\mathrm{a}}$ & $23.0^{a}$ & 1.28 & 0.001 \\
\hline \multicolumn{6}{|c|}{ Digestibility coefficient, $\mathrm{kg} / \mathrm{kg}$} \\
\hline Dry matter & 720 & 700 & 720 & 15.5 & 0.497 \\
\hline Organic matter & 740 & 730 & 750 & 12.2 & 0.571 \\
\hline Crude protein & 840 & 850 & 860 & 11.2 & 0.547 \\
\hline Neutral detergent fiber & $560^{b}$ & $650^{\mathrm{a}}$ & $700^{\mathrm{a}}$ & 14.6 & 0.001 \\
\hline Acid detergent fiber & $370^{b}$ & $600^{\mathrm{a}}$ & $620^{\mathrm{a}}$ & 17.0 & 0.001 \\
\hline
\end{tabular}

$\overline{a, b, c}$ Different letters indicate significant differences $(p<0.05)$. SEM $=$ standard error the mean. Forage:concentrate ratio $=$ forage (alfalfa hay and corn silage), concentrate (sorghum grain triticale grain, soybean meal, sunflower seeds (crushed or ensiled) and vitamin and mineral premix).

Table 4. Nitrogen balance ( $\mathrm{g} \mathrm{N} / \mathrm{d}, \mathrm{g} \mathrm{N} / \mathrm{kgLW}^{0.75}$ ) in dairy sheep fed control, sunflower seeds (SF), and sunflower seeds silage (SFS) treatments.

\begin{tabular}{|c|c|c|c|c|c|}
\hline \multirow{2}{*}{ N Balance } & \multicolumn{3}{|c|}{ Treatment } & \multirow{2}{*}{ SEM } & \multirow{2}{*}{$p$-Value } \\
\hline & Control & SF & SFS & & \\
\hline $\mathrm{N}$ intake, $\mathrm{g} / \mathrm{d}$ & 40.2 & 47.6 & 51.0 & 4.08 & 0.199 \\
\hline $\mathrm{N}$ intake, $\mathrm{g} / \mathrm{kg} \mathrm{LW} W^{0.75}$ & $2.06^{b}$ & $2.46^{\mathrm{a}}$ & $2.60^{\mathrm{a}}$ & 0.06 & 0.001 \\
\hline Fecal N excretion $\mathrm{g} / \mathrm{d}$ & 6.37 & 7.20 & 6.76 & 0.93 & 0.819 \\
\hline Fecal N g/kg LW ${ }^{0.75}$ & 0.32 & 0.37 & 0.34 & 0.03 & 0.597 \\
\hline Fecal N \% of N & 15.3 & 15.0 & 13.3 & 1.23 & 0.474 \\
\hline Urine $\mathrm{N}$ excretion $\mathrm{g} / \mathrm{d}$ & 2.69 & 3.54 & 4.72 & 0.59 & 0.087 \\
\hline Urine $\mathrm{N}$ g/kg LW ${ }^{0.75}$ & 0.14 & 0.18 & 0.25 & 0.04 & 0.201 \\
\hline Urine $\mathrm{N} \%$ of $\mathrm{N}$ & 7.14 & 7.64 & 10.0 & 1.89 & 0.537 \\
\hline Milk N excretion g/d & 9.93 & 11.2 & 8.27 & 2.19 & 0.630 \\
\hline Milk g/kg LW ${ }^{0.75}$ & 0.48 & 0.57 & 0.40 & 0.08 & 0.382 \\
\hline Milk \% of $\mathrm{N}$ & 22.8 & 23.2 & 15.1 & 3.53 & 0.220 \\
\hline Milk N retention g/d & $21.1^{b}$ & $24.5^{b}$ & $29.7^{\mathrm{a}}$ & 2.06 & 0.031 \\
\hline $\mathrm{N}$ balance $\mathrm{g} / \mathrm{kg} \mathrm{LW}^{0.75}$ & $1.59^{b}$ & $1.90^{\mathrm{a}}$ & $2.00^{\mathrm{a}}$ & 0.07 & 0.004 \\
\hline$\%$ Retained N & 54.0 & 51.8 & 58.6 & 3.74 & 0.448 \\
\hline
\end{tabular}

\footnotetext{
${ }^{\mathrm{a}, \mathrm{b}}$ Different letters indicate significant differences $(p<0.05)$. SEM $=$ standard error the mean.
} 
In this study, the absence of changes in nitrogen utilization was expected as dietary treatments were balanced to be isonitrogenous. In ruminant diets, energy supply is important for rumen microbial growth and has a deep impact on protein metabolism [27].

The positive $\mathrm{N}$ balance found with crushed sunflower seeds and sunflower silage points at the ability of both feedstuffs to deliver the required nitrogen for lactating ewes, while fulfilling protein needs for rumen microorganisms [11]. The oil contained in both SF and SFS diets did not affect the growth of cellulolytic bacteria, as suggested by the data about digestibility of NDF (Table 3). This probably favored a more efficient use of the ammonia originated by the rumen degradable protein of the SF and SFS diets. Our results also coincide with a positive $\mathrm{N}$ balance reported in lactating does fed whole sunflower seeds or linseed [24].

\subsection{Milk Yield and Milk Components}

Milk yield $(0.68 \pm 0.14 \mathrm{~kg} / \mathrm{d})$, milk fat yield $(38.4 \pm 9.12 \mathrm{~g} / \mathrm{d})$ and milk protein yield $(30.1 \pm 6.32 \mathrm{~g} / \mathrm{d})$ were not affected by treatments (Table 5). In sheep, concentrate-rich diets are expected to increase milk yields; however, that may lead to detrimental effects on lipid metabolism [28]. In goats fed on a corn silage-based diet and supplemented with sunflower oil, Bernard et al. [29] reported a rise in milk yield compared to their control treatment (no additional oil). However, in goats fed on a grass silage-based diet supplemented with whole seeds of sunflower or linseed, Vargas-Bello-Pérez et al. [24] did not find changes in milk yield and milk composition. Based on those studies, in the present study, the forage to concentrate ratio was around 57:47, and the lack of differences in milk production are partly explained by the amount of dietary forage that was supplied to the animals as ad libitum corn silage. Compared to concentrate-based diets, forage-based diets provide greater amounts of fiber (NDF and ADF) and lower non-structural carbohydrate content, such as sugars and starch [30] and this was reflected in our study.

Table 5. Milk yield and milk composition from dairy sheep fed control, sunflower seeds (SF), and sunflower seeds silage (SFS) treatments.

\begin{tabular}{cccccc}
\hline \multirow{2}{*}{ Item } & \multicolumn{5}{c}{ Treatment } \\
\cline { 2 - 5 } & Control & SF & SFS & SEM & Treatment \\
\hline Milk Yield, kg/d & 0.64 & 0.78 & 0.62 & 0.14 & 0.695 \\
Fat-corrected milk 6.5\% & 0.63 & 0.72 & 0.52 & 0.14 & 0.603 \\
FPCM 6.5, 5.8\% & 0.60 & 0.69 & 0.52 & 0.13 & 0.647 \\
Feed Efficiency & 0.32 & 0.35 & 0.26 & 0.05 & 0.359 \\
Feed Efficiency FCM & 0.30 & 0.34 & 0.25 & 0.04 & 0.404 \\
Milk-N/ N-Intake\% & 0.22 & 0.27 & 0.22 & 0.03 & 0.503 \\
MUN, mg/dl & 74.8 & 95.4 & 105 & 11.4 & 0.199 \\
\hline Fat & Milk composition, g/100g & & \\
Protein & 5.78 & 5.69 & 4.79 & 0.43 & 0.810 \\
Lactose & $4.23^{\mathrm{b}}$ & $4.38^{\mathrm{ab}}$ & $4.58^{\mathrm{a}}$ & 0.10 & 0.043 \\
Non-fat solids & $4.00^{\mathrm{b}}$ & $4.15^{\mathrm{ab}}$ & $4.34^{\mathrm{a}}$ & 0.10 & 0.042 \\
Total solids & $8.93^{\mathrm{b}}$ & $9.29 \mathrm{ab}$ & $9.72^{\mathrm{a}}$ & 0.22 & 0.027 \\
Fat & 22.9 & 23.5 & 23.4 & 0.56 & 0.752 \\
\hline Protein & \multicolumn{2}{c}{ Milk composition, g/d } & & \\
Lactose & 40.7 & 44.1 & 30.5 & 9.12 & 0.541 \\
Non-fat solids & 26.4 & 34.8 & 29.0 & 6.32 & 0.468 \\
Total solids & 25.0 & 32.9 & 27.5 & 5.98 & 0.466 \\
\hline
\end{tabular}

a,b Mean values for each experiment within a row with unlike superscript letters were significantly different $(p<$ 0.05). SEM = standard error the mean. Fat-corrected milk $($ FCM $6.5 \%, \mathrm{~kg} / \mathrm{d})=[\mathrm{milk}(\mathrm{kg} / \mathrm{d}) \times(0.37+$ fat $\%) \times 0.097]$, Fat-Protein corrected milk (FPCM 6.5, 5.8\%, kg/d) $=[$ milk $(\mathrm{kg} / \mathrm{d}) \times(0.25+0.085 \mathrm{fat} \%+0.035$ protein $\%)]$, Feed Efficiency $=$ Milk (kg/d)/DMI (kg/d), Adjusted Feed Efficiency FCM6.5\% = FCM6.5\% (Kg/d)/DMI (kg/d). Milk-N/ N-Intake $\%($ Milk N, kg/d/ N intake, kg/d × 100,) MUN, mg/dL = milk urea nitrogen. 
Compared with control and SF, SFS increased contents $(\mathrm{g} / 100 \mathrm{~g})$ of protein, lactose, and non-fat solids (Table 5). These results suggest that SFS was able to supply enough $\mathrm{N}$ for rumen microbial protein synthesis and this was later revealed in the secreted milk. This finding on milk protein contents reinforce the observed positive $\mathrm{N}$ balance that was earlier discussed in this manuscript. Moreover, the increase in milk protein by SFS may be due to the fact that this treatment may have been able to provoke rumen defaunation of ciliated protozoa and that led to increases in rumen microbial synthesis of protein [21].

Milk fat content (5.42 $\pm 0.43 \mathrm{~g} / 100 \mathrm{~g})$ and yield were similar between treatments (Table 5). Compared with cows, sheep and goats are more resilient to dietary supplements rich in polyunsaturated fatty acids, such as oilseeds by-products. In this study, we fed animals with two types of sunflower seed presentation (crushed and ensiled) and in both cases they did not induce milk fat depression. One explanation to the different responses to dietary lipids between ruminant species is that there are differences in their rumen bacterial structure, especially in goats [31]. However, when diet provides enough amount of effective fiber, no reductions in milk fat have been observed in both small and large ruminants [32-35]. According to Chilliard et al. [36], if the concentrate does not exceed 60\% of the diet, the milk fat content is not much affected, whereas a significant decrease is often observed beyond $60 \%$. In the present experiment, SF and SFS diets were associated with higher intake of NDF that probably avoid detrimental effect of the highest content of dietary unsaturated fatty acids on rumen cellulolytic bacteria. Future studies should analyze the effects of SF and SFS on milk fatty acid profile as today consumers are more aware on the benefits and disadvantages from consuming milk fat [37], and in the case of the present study, it will be expected to obtain reductions in fatty acids derived from de novo synthesis and odd- and branched- chain fatty acids [38].

\subsection{In Vitro Gas Production}

The fractional rate of degradation (c) and lag time were not affected by treatments (Table 6). Gas production at 12 and $24 \mathrm{~h}$ was higher for SFS. Compared with control, SF and SFS decreased DM disappearance at $96 \mathrm{~h}$. Although no pure sunflower oil was used in this study, it is possible that the oil contained in the sunflower seeds either crushed or ensiled, was sufficient to disrupt the rumen microbial ecosystem as fat coats feed particles, affecting microbial fermentation [39].

Table 6. In vitro rumen gas kinetics ( $\mathrm{mL}$ gas/ g DM) and fermentation profile of different diets in dairy sheep fed control, sunflower seeds (SF) and sunflower seeds silage (SFS) treatments.

\begin{tabular}{cccccc}
\hline Item & Control & SFS & SFS & SEM & $p$-Value \\
\hline A & 186 & 183 & 174 & 5.08 & 0.298 \\
B & 0.044 & 0.038 & 0.050 & 0.008 & 0.665 \\
C & 0.002 & 0.003 & 0.012 & 0.017 & 0.903 \\
Lag time & 0.258 & 0.352 & 0.218 & 0.079 & 0.931 \\
\hline & & Gas production, mL gas/g DM & & \\
$12 \mathrm{~h}$ & $85^{\mathrm{ab}}$ & $77^{\mathrm{b}}$ & $90^{\mathrm{a}}$ & 2.56 & 0.001 \\
$24 \mathrm{~h}$ & $124^{\mathrm{a}}$ & $112^{\mathrm{b}}$ & $122^{\mathrm{a}}$ & 2.73 & 0.001 \\
$48 \mathrm{~h}$ & $158^{\mathrm{a}}$ & $152^{\mathrm{b}}$ & $150^{\mathrm{b}}$ & 2.61 & 0.001 \\
$96 \mathrm{~h}$ & $188^{\mathrm{a}}$ & $181^{\mathrm{b}}$ & $176^{\mathrm{b}}$ & 3.03 & 0.001 \\
pH & 6.78 & 6.79 & 6.77 & 0.02 & 0.685 \\
DMD 96 h & $84.9^{\mathrm{a}}$ & $83.2^{\mathrm{b}}$ & $83.0^{\mathrm{b}}$ & 0.30 & 0.007 \\
PF 96 h & 221 & 218 & 212 & 4.12 & 0.326 \\
GY 24 h & 29.2 & 26.9 & 29.4 & 0.62 & 0.057 \\
SCFA & 0.55 & 0.49 & 0.54 & 0.01 & 0.056 \\
MCP & $794^{\mathrm{a}}$ & $782^{\mathrm{ab}}$ & $776^{\mathrm{b}}$ & 2.79 & 0.001 \\
\hline
\end{tabular}

a,b Mean values for each experiment within a row with unlike superscript letters were significantly different $(p<$ 0.05). $\mathrm{SEM}=$ standard error the mean. $\mathrm{A}=$ total gas production ( $\mathrm{ml}$ gas $/ \mathrm{g} \mathrm{DM}$ incubated); $\mathrm{B}=$ fermentation rate $\left(\mathrm{h}^{-1}\right) ; \mathrm{C}=$ fermentation rate $\left(\mathrm{h}^{-1 / 2}\right) ;$ Lag time $=$ the initial delay before gas production begins $(\mathrm{h}) ; \mathrm{DMD} 96=\mathrm{DM}$ degraded substrate (mg/g DM); GY24 = gas yield at $24 \mathrm{~h}(\mathrm{~mL}$ gas/g DMD); SCFA = short chain fatty acids (mmol/g $\mathrm{DM}) ; \mathrm{MCP}=$ microbial CP production $(\mathrm{mg} / \mathrm{g} \mathrm{DM})$. 
Compared with control and SF, microbial crude protein production was reduced by SFS (Table 6). Normally, fat, oils, and grease are related to diminished microbial activity [40] and this was reflected in the reductions of microbial crude protein provoked by both types of sunflower presentations. These results are in contrast with in vivo data obtained from the present study, probably due to the use of "in batch" fermentation. According to the in vivo results, NDF and ADF digestibility was greater in SF and SFS diets, and, likely, the microbial protein production was also enhanced, as suggested by the higher N retention. Ewes fed SF and SFS diets increased concentrate and NDF intake per kg of live weight, due to the higher NDF content of SF and SFS that, in turn, likely stimulated the passage rate of diet ingredients. This likely reduced the inhibitory effect of vegetable oil on cellulolytic bacteria. When fermentation was investigated by "in batch" system, the effect of passage rate was not evaluable. To support our findings, future studies should consider analyzing in detail in vitro rumen simulation technique (i.e., RUSITEC system) or in vivo feeding trials focused on rumen microbiome.

\section{Conclusions}

Overall, our results highlight the importance of the basal diet composition on responses related to milk yield, milk composition, nutrient degradation, nutrient intake, and $\mathrm{N}$ balance in dairy sheep. Results demonstrated that crushed sunflower seeds and ensiled seeds do not change significantly productive parameters of dairy sheep. In corn-silage based diets, both crushed and ensiled sunflower seeds, could be used in dairy sheep diets as alternatives for protein feedstuffs.

Author Contributions: Conceptualization, M.G.-R., E.C.-G., L.E.R.-J., and E.B.V.P.; methodology, M.G.-R., L.E.R.-J., E.C.-G., A.C.N.-L.; software M.G.-R., L.E.R.-J.; validation, E.V.-B.-P., M.G.-R., and L.E.R.-J.; formal analysis, E.C.-G. and A.C.N.-L.; investigation, M.G.-R., L.E.R.-J., E.C.-G., A.C.N.-L.; resources, M.G.-R. data curation, E.V.-B.-P., M.G.-R., L.E.R.-J.; writing-original draft preparation, M.G.-R., L.E.R.-J., E.C.-G., E.V.-B.-P., H.L., and M.M. writing-review and editing, M.G.-R., L.E.R.-J., E.C.-G., E.V.-B.-P., A.M.O., M.d.G.G.-M., H.L., and M.M., visualization, M.G.-R., L.E.R.-J., E.C.-G.; supervision, M.G.-R. and E.V.-B.-P. project administration, M.G.-R.; funding acquisition, M.G.-R. All authors have read and agreed to the published version of the manuscript.

Funding: This research was funded by Universidad Autónoma del Estado de México, grant number 4974/2020CIB. During the study, Dr. Einar Vargas-Bello-Pérez was a visiting scholar, also supported by project number 4974/2020CIB.

Acknowledgments: The authors thanked the animal nutrition staff 2019 from the Veterinary Faculty and Livestock production.

Conflicts of Interest: The authors declare no conflict of interest.

\section{References}

1. Ortiz-Hernandez, A.A.; Araiza-Esquivel, M.; Delgadillo-Ruiz, L.; Ortega-Sigala, J.J.; Durán-Muñoz, H.A.; Mendez-Garcia, V.H.; Yacaman, M.J.; Vega-Carrillo, H.R. Physical characterization of sunflower seeds dehydrated by using electromagnetic induction and low-pressure system. Innov. Food Sci. Emerg. Technol. 2020, 60, 102285. [CrossRef]

2. Canibe, N.; Pedrosa, M.M.; Robredo, L.M.; Bach Knudsen, K.E. Chemical composition, digestibility and protein quality of 12 sunflower (Helianthus annuus L.) cultivars. J. Sci. Food Agric. 1999, 79, 1775-1782. [CrossRef]

3. Thomas, V.M.; Murray, G.A.; Thacker, D.L.; Sneddon, D.N. Sunflower Silage in Rations for Lactating Holstein Cows1, 2. J. Dairy Sci. 1982, 65, 267-270. [CrossRef]

4. Zagorakis, K.; Liamadis, D.; Milis, C.; Dotas, V.; Dotas, D. Nutrient digestibility and in situ degradability of alternatives to soybean meal protein sources for sheep. Small Rumin. Res. 2015, 124, 38-44. [CrossRef]

5. Parisi, G.; Tulli, F.; Fortina, R.; Marino, R.; Bani, P.; Zotte, A.D.; de Angeli, A.; Piccolo, G.; Pinotti, L.; Schiavone, A.; et al. Protein hunger of the feed sector: The alternatives offered by the plant world. Ital. J. Anim. Sci. 2020, 19, 1205-1227. [CrossRef]

6. Zhang, R.H.; Mustafa, A.F.; Zhao, X. Effects of feeding oilseeds on nutrient utilization by lactating ewes. Small Rumin. Res. 2007, 67, 307-311. [CrossRef]

7. Amores, G.; Virto, M.; Nájera, A.I.; Mandaluniz, N.; Arranz, J.; Bustamante, M.A.; Valdivielso, I.; de Gordoa, J.R.; García-Rodríguez, A.; Barron, L. Rapeseed and sunflower oilcake as supplements for dairy sheep: Animal performance and milk fatty acid concentrations. J. Dairy Res. 2014, 81, 410. [CrossRef] 
8. Cabiddu, A.; Addis, M.; Fiori, M.; Spada, S.; Decandia, M.; Molle, G. Pros and cons of the supplementation with oilseed enriched concentrates on milk fatty acid profile of dairy sheep grazing Mediterranean pastures. Small Rumin. Res. 2017, 147, 63-72. [CrossRef]

9. Martínez, J.R.P.F.; Huerta, A.G.; López, D.D.J.P.; Cuevas, R.S.; Salem, A.Z.M.; Robles-Jimenez, L.E.; Gonzalez-Ronquillo, M. Effect of xylanase, cellulase and natural maguey extract on the chemical composition of corn silage and in vitro rumen gas production. Int. J. Agric. Nat. Resour. 2020, 47, 23-34.

10. Escalante, A.; López Soto, D.R.; Velázquez Gutiérrez, J.E.; Giles-Gómez, M.; Bolívar, F.; López-Munguía, A. Pulque, a Traditional Mexican Alcoholic Fermented Beverage: Historical, Microbiological, and Technical Aspects. Front. Microbiol. 2016, 7, 1026. [CrossRef]

11. NRC. Nutrient Requirements of Small Ruminants: Sheep, Goats, Cervids, and New World Camelids; National Academies Press: Washington, DC, USA, 2007; p. 362.

12. AOAC. Association of Official Analytical Chemists. Official Methods of Analysis, 18th ed.; AOAC: Gaithersburg, MD, USA, 2005; p. 432.

13. Van Soest, P.J.; Robertson, J.B.; Lewis, B.A. Methods for dietary fiber, neutral detergent fiber, and nonstarch polysaccharides in relation to animal nutrition. J. Dairy Sci. 1991, 74, 3583-3597. [CrossRef]

14. McKenzie, H.A.; Murphy, W.H. General methods and elemental analysis. Determination of total nitrogen. In Milk Proteins; McKenzie, H.A., Ed.; Academic Press: New York, NY, USA, 1970; Volume 1, pp. 154-161.

15. Levowitz, D. An Appraisal of the Gerber Test for Milk Fat in Milk and Market Milk Products1. J. Milk Food Technol. 1960, 23, 69-72. [CrossRef]

16. Pulina, G.; Macciotta, N.; Nudda, A. Milk composition and feeding in the Italian dairy sheep. Ital. J. Anim. Sci. 2005, 4, 5-14. [CrossRef]

17. Theodorou, M.K.; Williams, B.A.; Dhanoa, M.S.; McAllan, A.B.; France, J. A simple gas production method using a pressure transducer to determine the fermentation kinetics of ruminant feeds. Anim. Feed Sci. Technol. 1994, 48, 185-197. [CrossRef]

18. Vargas-Bello-Pérez, E.; Robles-Jimenez, L.E.; Ayala-Hernández, R.; Romero-Bernal, J.; Pescador-Salas, N.; Castelán-Ortega, O.A.; González-Ronquillo, M. Effects of Calcium Soaps from Palm, Canola and Safflower Oils on Dry Matter Intake, Nutrient Digestibility, Milk Production, and Milk Composition in Dairy Goats. Animals 2020, 10, 1728. [CrossRef]

19. France, J.; Dhanoa, M.S.; Theodorou, M.K.; Lister, S.J.; Davies, D.R.; Isac, D. A Model to Interpret Gas Accumulation Profiles Associated with In Vitro Degradation of Ruminant Feeds. J. Theor. Biol. 1993, 163, 99-111. [CrossRef]

20. Khotijah, L.; Pandiangan, E.I.; Astuti, D.A.; Wiryawan, K.G. Effect of Sunflower Oil Supplementation as Unsaturated Fatty Acid Source on Rumen Fermentability and Performance of Lactating Garut Ewes. J. Indones. Trop. Anim. Agric. 2017, 42, 185-193. [CrossRef]

21. Ivan, M.; Mir, P.S.; Mir, Z.; Entz, T.; He, M.L.; McAllister, T.A. Effects of dietary sunflower seeds on rumen protozoa and growth of lambs. Br. J. Nutr. 2004, 92, 303-310. [CrossRef]

22. Gómez-Cortés, P.; de la Fuente, M.A.; Toral, P.G.; Frutos, P.; Juárez, M.; Hervás, G. Effects of different forage:concentrate ratios in dairy ewe diets supplemented with sunflower oil on animal performance and milk fatty acid profile. J. Dairy Sci. 2011, 94, 4578-4588. [CrossRef]

23. Lock, A.L.; Teles, B.M.; Perfield, J.W., 2nd; Bauman, D.E.; Sinclair, L.A. A conjugated linoleic acid supplement containing trans-10, cis-12 reduces milk fat synthesis in lactating sheep. J. Dairy Sci. 2006, 89, 1525-1532. [CrossRef]

24. Vargas-Bello-Pérez, E.; García Montes de Oca, C.A.; Pescador Salas, N.; Estrada Flores, J.G.; Bernal, J.R.; Robles-Jimenez, L.E.; Gonzalez-Ronquillo, M. Productive Performance, Milk Composition and Milk Fatty Acids of Goats Supplemented with Sunflower and Linseed Whole Seeds in Grass Silage-Based Diets. Animals 2020, 10, 1143. [CrossRef] [PubMed]

25. Martínez Marín, A.L.; Gómez-Cortés, P.; Gómez Castro, G.; Juárez, M.; Pérez Alba, L.; Pérez Hernández, M.; de la Fuente, M.A. Effects of feeding increasing dietary levels of high oleic or regular sunflower or linseed oil on fatty acid profile of goat milk. J. Dairy Sci. 2012, 95, 1942-1955. [CrossRef]

26. Hristov, A.N.; Ropp, J.K.; Grandeen, K.L.; Abedi, S.; Etter, R.P.; Melgar, A.; Foley, A.E. Effect of carbohydrate source on ammonia utilization in lactating dairy cows. J. Anim. Sci. 2005, 83, 408-421. [CrossRef] [PubMed] 
27. Vargas-Bello-Pérez, E.; Márquez-Hernández, R.I.; Hernández-Castellano, L.E. Bioactive peptides from milk: Animal determinants and their implications in human health. J. Dairy Res. 2019, 86, 136-144. [CrossRef] [PubMed]

28. Angeles-Hernandez, J.C.; Vieyra Alberto, R.; Kebreab, E.; Appuhamy, J.A.D.R.N.; Dougherty, H.C.; Castelan-Ortega, O.; Gonzalez-Ronquillo, M. Effect of forage to concentrate ratio and fat supplementation on milk composition in dairy sheep: A meta-analysis. Livest. Sci. 2020, 238, 104069. [CrossRef]

29. Bernard, L.; Shingfield, K.J.; Rouel, J.; Ferlay, A.; Chilliard, Y. Effect of plant oils in the diet on performance and milk fatty acid composition in goats fed diets based on grass hay or maize silage. Br. J. Nutr. 2009, 101, 213-224. [CrossRef]

30. Mierlita, D.; Maerescu, C.; Daraban, S.; Lup, F. Effects of Energy and Protein Content in the Diet on Milk Yield and Milk Fatty Acid Profile in Dairy Ewes. Bulletin of University of Agricultural Sciences and Veterinary Medicine Cluj-Napoca. Anim. Sci. Biotechnol. 2009, 66, 3326. [CrossRef]

31. Ferlay, A.; Bernard, L.; Meynadier, A.; Malpuech-Brugère, C. Production of trans and conjugated fatty acids in dairy ruminants and their putative effects on human health: A review. Biochimie 2017, 141, 107-120. [CrossRef]

32. Kennelly, J.J. The fatty acid composition of milk fat as influenced by feeding oilseeds. Anim. Feed Sci. Technol. 1996, 60, 137-152. [CrossRef]

33. Mele, M.; Buccioni, A.; Petacchi, F.; Serra, A.; Banni, S.; Antongiovanni, M.; Secchiari, P. Effect of forage/concentrate ratio and soybean oil supplementation on milk yield, and composition from Sarda ewes. Anim. Res. 2006, 55, 273-285. [CrossRef]

34. Mele, M.; Serra, A.; Buccioni, A.; Conte, G.; Pollicardo, A.; Secchiari, P. Effect of soybean oil supplementation on milk fatty acid composition from Saanen goats fed diets with different forage:concentrate ratios. Ital. J. Anim. Sci. 2008, 7, 297-311. [CrossRef]

35. Bionaz, M.; Vargas-Bello-Pérez, E.; Busato, S. Advances in fatty acids nutrition in dairy cows: From gut to cells and effects on performance. J. Anim. Sci. Biotechnol. 2020, 11, 110. [CrossRef]

36. Chilliard, Y.; Glasser, F.; Ferlay, A.; Bernard, L.; Rouel, J.; Doreau, M. Diet, rumen biohydrogenation and nutritional quality of cow and goat milk fat. Eur. J. Lipid Sci. Technol. 2007, 109, 828-855. [CrossRef]

37. Vargas-Bello-Pérez, E.; Faber, I.; Osorio, J.S.; Stergiadis, S. Consumer knowledge and perceptions of milk fat in Denmark, the United Kingdom, and the United States. J. Dairy Sci. 2020, 103, 4151-4163. [CrossRef]

38. Vlaeminck, B.; Fievez, V.; Cabrita, A.R.J.; Fonseca, A.J.M.; Dewhurst, R.J. Factors affecting odd- and branched-chain fatty acids in milk: A review. Anim. Feed Sci.Technol. 2006, 131, 389-417. [CrossRef]

39. Vargas-Bello-Pérez, E.; Cancino-Padilla, N.; Romero, J.; Garnsworthy, P.C. Quantitative analysis of ruminal bacterial populations involved in lipid metabolism in dairy cows fed different vegetable oils. Animal 2016, 10, 1821-1828. [CrossRef]

40. Kurade, M.B.; Saha, S.; Salama, E.-S.; Patil, S.M.; Govindwar, S.P.; Jeon, B.-H. Acetoclastic methanogenesis led by Methanosarcina in anaerobic co-digestion of fats, oil and grease for enhanced production of methane. Bioresour. Technol. 2019, 272, 351-359. [CrossRef]

Publisher's Note: MDPI stays neutral with regard to jurisdictional claims in published maps and institutional affiliations.

(C) 2020 by the authors. Licensee MDPI, Basel, Switzerland. This article is an open access article distributed under the terms and conditions of the Creative Commons Attribution (CC BY) license (http://creativecommons.org/licenses/by/4.0/). 